\title{
LGBT RIGHTS ARE HUMAN RIGHTS: SOCIAL WORK AND THE FIGHT AGAINST THE LGBTPHOBIC DISCOURSE OF "GAY CURE”
}

\section{DIREITOS LGBT SÃO DIREITOS HUMANOS: O SERVIÇO SOCIAL E O COMBATE AO DISCURSO LGBTFÓBICO DA "CURA GAY"}

\author{
Leo Mozdzenski ${ }^{1}$, Albert de Albuquerque ${ }^{2}$ \\ 1 Universidade Federal de Pernambuco, Programa de Pós-Graduação em Direitos Humanos, Brasil, \\ e-mail: leo_moz@yahoo.com.br, ORCID: https://orcid.org/0000-0002-4010-5507 \\ 2 Universidade Federal de Pernambuco, Departamento de Serviço Social, Brasil, e-mail: \\ albert.seso@gmail.com, ORCID: https://orcid.org/0000-0002-3300-066X
}

\section{ARTICLE IN F O}

Article history:

Received 2020-05-02

Accepted 2020-06-20

Available online 2020-06-20
Keywords: Human rights. LGBTphobia. Social Work. Critical Discourse Analysis. Rhetoric.

Palavras-chave: Direitos humanos. LGBTfobia. Serviço Social. Análise Crítica do Discurso. Retórica.

\begin{abstract}
This paper proposes to critically examine the LGBTphobic comments of social workers against the content of the video For Social Work there is no "gay cure", created by the Brazilian Federal Council of Social Work (CFESS). Thus, based on the theoretical and methodological principles of Critical Discourse Analysis (CDA), this research investigates how the construction of meanings of the arguments made in those prejudiced posts proceeds. CDA proposes to describe, interpret and disseminate how forms of power, domination and social inequality are (re)produced in discursive practices, in their socio-political and cultural contexts. More particularly, this study turns its attention to the rhetorical appeals of ethos and pathos observed in those statements that were favorable to the proposition of therapies for sexual (re)orientation ("gay cure"), thus reproducing the hate speech, stigmatization and discrimination against the human rights of the members of the gender and sexuality diverse community. The findings can be arranged into five analytical categories: the cis-hetero-compulsory rhetoric, the "freedom of thought" rhetoric, the "right to choose" rhetoric, the neoconservative rhetoric and the religious rhetoric.
\end{abstract}

RESUMO. Este trabalho propõe examinar criticamente os comentários LGBTfóbicos de assistentes sociais contrários ao conteúdo do vídeo Para o Serviço Social não existe "cura gay", criado pelo Conselho Federal de Serviço Social. Desse modo, fundamentando-se nos preceitos teórico-metodológicos da Análise Crítica do Discurso ( $A C D$ ), a presente pesquisa investiga como se processa a construção de sentidos dos argumentos desferidos nessas postagens preconceituosas. A ACD propõe descrever, interpretar e divulgar como as formas de poder, a dominação e a desigualdade social são (re)produzidas nas práticas discursivas, em seus contextos sociopolíticos e culturais de funcionamento. Mais particularmente, este estudo volta sua atenção aos apelos retóricos do ethos e do pathos observados nesses enunciados que se mostraram favoráveis à proposição das terapias de (re)orientação sexual ("cura gay"), reproduzindo, assim, o discurso de ódio, estigmatização e discriminação contra os direitos humanos dos membros da comunidade sexodissidente. Os achados podem ser dispostos em cinco categorias analíticas: a retórica cisheterocompulsória, a retórica da "liberdade do pensamento", a retórica do "direito de escolha", a retórica neoconservadora e a retórica religiosa. 


\section{Introduction ${ }^{1}$}

In September 2017, the Brazilian Federal Council of Social Work (CFESS) released on its digital social networks the video For Brazilian Social Work, there is no "gay cure" (CFESS, 2017a, 2017b). The material was produced in support of the LGBT $^{2}$ community, in response to the court decision that set precedents for psychologists to offer "sexual (re)orientation therapies" - a psychotherapeutic treatment popularly called "gay cure".

The Brazilian Social Worker's Code of Ethics (CFESS Resolution nr. 273/1993) expressly determines that the exercise of Social Work must occur without any type of discrimination due to sexual orientation and gender identity, and that the social workers must strive to eliminate all forms of prejudice. Despite this, it is possible to observe the occurrence of several LGBTphobic comments to the video, posted in support - manifest or veiled - to the fallacious rhetoric of "gay cure", having been carried out by internet users who present themselves as professionals or students of Social Work.

In view of this disparate scenario, this paper proposes to critically examine the LGBTphobic arguments of self-identified internet users as social workers against the content of the video For Brazilian Social Work, there is no "gay cure", by CFESS. More specifically, the objective is to unravel how the rhetorical appeals of ethos and pathos are constructed in the statements of those professionals in favor of the "gay cure" proposition, reproducing the discourse of stigmatization and prejudice against the gender and sexuality diverse community.

\section{LGBT rights are human rights}

After about a decade of discussions, the United Nations (UN) finally established that LGBT rights are human rights, according to Resolution $\mathrm{nr}$. A/HRC/RES/17/19, passed in the United Nations Human Rights Council (UNHRC) on June 17, 2011. In the text of the Resolution, the UNHRC expresses grave concern about acts of violence and discrimination practiced around the world against individuals because of their sexual orientation and gender identity. Thus, the document stipulates that a country that does not care for its sexually diverse population will be in violation of international human rights treaties and conventions.

\footnotetext{
${ }^{1}$ This paper resumes, revises and deepens the work presented by the authors at the IV Seminário Internacional Desfazendo Gênero (Recife, Pernambuco, Brazil, 13-15 November 2019).

2 Acronym that stands for Lesbians, Gays, Bisexuals, and Transgenders. Currently, it is possible to observe the use of other derivative initialisms, such as LGBTQ (with the letter Q indicating queer people, being more present in American social movements), LGBTI (with the letter I indicating intersex people, used frequently by international entities, such as the United Nations and Amnesty International) or, more recently, LGBTQIA + (with the letter A indicating asexual people and the + sign representing other gender identities/sexualities not covered by the previous letters). In this paper, the acronym LGBT will be used, as it is the most commonly used term in Brazilian research, media and official documents. In any case, the use of the initialism here refers to any non-heterosexual and/or non-cisgender person.
} 
For that matter, with regard to Brazil and much of Latin America, Vecchiatti (2019) points out that it has been possible to observe a significant advance in the last three decades in respect of legal protection and public policies directed at the LGBT community. However, much more recently, it is feared that these achievements may be undermined due to the radical transformation of the political sphere in some of these countries. In the Brazilian scenario, in particular, this threat has been materializing in the face of the abrupt rise of a government that flirts with the extreme right, leveraged by conservative interest groups and social movements - especially of a religious nature - that are opposed to the LGBT agenda.

At the linguistic-discursive level, this current fundamentalist ideological trend is marked by the prevalence of moralistic and reactionary rhetoric. And often, the argument falls to the manipulation of the public, mainly through the mass media and the new digital media. Charaudeau (2016) thoroughly discusses this subject, arguing that manipulative discourses have basically four fundamental characteristics.

First, manipulators never reveal their real purposes, camouflaging them in the form of an opposing discourse or even assuming the appearance of acting for the benefit of the manipulated. Second, aiming to impress the manipulated, manipulators use a position of legitimacy, that is given by the context. In other words, they occupy a prestigious place and are socially recognized as an institutionally legitimate authority in that situation. Third, manipulators build an ethos, that is, an image of themselves capable of paralyzing the opinion of the manipulated, either through threat or through seduction. Fourth, manipulators dramatize their speech in a way that disturbs the manipulated, and may even terrify their audience.

The manipulative discourse seeks to provoke an incentive for the public to change their conviction about a certain topic, adhering to the position of the manipulator. To that end, according to Charaudeau (2016), this type of discourse often resorts to pathos, that is, arguments of emotional or ethical appeal (hatred, fear, compassion, etc.), and often makes explicit a source of evil (person or group) responsible for social disorder, who should be denounced as a scapegoat. Lastly, it is also usual for the manipulative discourse to propose or imply a saving solution, embodied in the image of a "savior of the day", a defender of morals, good manners and well behaved citizens, who is committed to repairing the disorder.

Thus, the relevance of this paper is evidenced by the importance and urgency to turn academy's attention to the queer population, that is, to all sexual and gender diversity, to all who are not heterosexual, cisgender, or gender-binary. It is necessary to embrace and make visible especially those who have been historically marginalized and vulnerable, the deviants, those who are neither suited to heteronormativity, nor even homonormativity. They are feminine gay men, masculine lesbian women, trans individuals, intersexuals, asexuals, non- 
binaries, fluid genders, drag queens, drag kings, crossdressers, androgynous, among so many other people and experiences that reject watertight labels and categorizations.

These disruptive subjects are the main targets of the hatred distilled in LGBTphobic comments on social media. Furthermore: comments made even by those professionals who should provide those citizens with assistance free from prejudice and stigma, supporting collective equality and human rights. This paradoxical phenomenon deserves a closer look at its tensions, as Freire Filho (2013, p. 17-18) argues:

\begin{abstract}
Anger has, in short, complex and different reasons, sources, meanings, purposes. Investigating its manifestations in virtual environments can provide very concrete clues about the values, identities and practices that different groups or communities feel that it is important to preserve or modify today.
\end{abstract}

Moreover, the indiscriminate spread of manipulative and hateful discourse on social media networks ends up constellating and naturalizing expressions of symbolic violence capable of hindering or even preventing the agency of the members of the gender and sexual diverse community, denying their entry into the political arena and spaces of power. Ultimately, the overblown reiteration of this LGBTphobic rhetoric on digital platforms may even restrict these individuals' access to affirmative public policies, inducing public opinion to unfavorably assess all those who escape the hegemonic pattern of sexuality and gender identity.

\title{
3. Critical Discourse Analysis and Rhetoric
}

With regard to the theoretical and methodological aspects, this study uses the investigative strategies proposed by Critical Discourse Analysis (CDA). CDA is the generic name attributed to a common project to study speech, writing, and other semiosis (image, sound, music, etc.), which proposes to describe, interpret, and disseminate how forms of power, domination and social inequality are (re)produced in discursive practices, in their socio-political and cultural contexts of functioning.

Actually, CDA is not a school or a discipline. It is rather the adoption of an openly critical and politicized posture of researching, identifying, and exposing what is implicit or naturalized in oral, written and multisemiotic texts, and which, in some way, has effects on the freedom of thought and the individual action possibilities of the subjects. According to Van Dijk (2003), all theoretical and methodological planning is shown to be adequate whenever it allows discursively examining relevant social problems, such as racism, sexism, xenophobia, and other forms of social discrimination.

Thus, aiming to show how the constitution of the LGBTphobic discourse among Brazilian Social Work professionals takes place, this research will resort to the rhetorical 
notions of ethos and pathos to investigate the corpus. Therefore, it is necessary to briefly discuss these concepts and how they operate in the production of meanings in the text.

The notions of ethos and pathos were born with the practice of oratory and rhetoric in ancient Greece and Rome. ${ }^{3}$ The traditional Aristotelian trilogy of evidence - also known as "appeals" - involves the following elements: ethos, which consists of making a good impression by the way the speaker constructs their speech, producing an image of themself capable of convincing the audience and gain its accession; pathos, which refers to the types of sentimental appeal and the importance given to the audience, considering how to keep people's trust and win their support through emotion; and logos, which deals with the logical discursive construction of the argument, as well as the types of reasoning used by the speaker (ARISTÓTELES, 2007; LEACH, 2002).

Nowadays, in the realm of Discourse Analysis, ethos is understood as the self-image produced by the speaker at the moment they begin to speak (MAINGUENEAU, 2008). Pathos, on the other hand, refers to the discursive expression of the speaker's feelings in order to move the audience and obtain their endorsement in the face of the proposed ideas (CHARAUDEAU, 2007). These two concepts are intrinsically associated with each other, and, unlike classical rhetoric, they can also be associated with written and multisemiotic texts. Building identities and staging emotions are the two sides of any communicative situation.

In short, ethos is related to discursive cues (verbal and non-verbal) that show how the speaker/writer sees themself and how they want others to see them - whether they can be successful or not in this endeavor. Pathos, on the other hand, can be understood as any discursive aspects that, in a given situation, would be able to trigger an emotional response in the audience. Pathos does not imply the certainty or guarantee of provoking feelings, sensations or reactions in the interlocutors. Rather, it consists of an attempt, an expectation or a possibility to bring out emotional states in listeners, readers, or viewers.

Thus, the researchers' mission is to investigate the potential identity (of the speaker/ writer) and the pathemic (affective) dimensions present in the argument as well as in the linguistic and multisemiotic materiality of a text. So the purpose here is to examine how the interlocutor - individual or group of people - can be persuaded to accept those causes defended by the speaker/writer, evoking certain emotional states associated with a credible image of the orator/author.

Hence, in view of this theoretical and methodological apparatus, this paper proposes to examine how the constitution of ethos and pathos is processed in the comments of

\footnotetext{
${ }^{3}$ Rhetoric is here conceived, on the one hand, as the discipline that studies the way we communicate persuasively with each other and, on the other hand, as the very activity of a speaker or writer who seeks to influence and discursively shape the way their interlocutor/ audience thinks or acts in relation to a certain theme (MATEUS, 2018). For a more in-depth discussion of ethos and pathos, see Mozdzenski (2012).
} 
professionals and students of Social Work in response to the video entitled For Social Work, there is no "gay cure", by CFESS. Namely, the corpus is composed of statements that corroborate the fallacious and prejudiced rhetoric of the so-called "gay cure".

\section{Social Work and the fight against LGBTphobia}

Historically, it is possible to observe that Social Work in Brazil has been promoting more and more the discussion about confronting the LGBTphobic discourse, especially with regard to making human rights feasible for the gender and sexuality diverse community. However, this is a topic that still generates a lot of controversy and produces enormous challenges among social workers, as pointed out by Menezes and Silva (2017, p. 123):

On the one hand, there is some resistance from professionals and students [of Social Work] in debating and dealing with the theme of homophobia in academia and in their professional contexts, often sharing a posture focused on professional conservatism surrounded by the absence of recognition the right to free expression of human affectivity and sexuality. On the other hand, it is a professional category that has presented significant theoretical and practical advances in what concerns the search for the defense of the rights of the LGBT population, treating homophobia as an expression of the social question that must be combated by all.

According to Duarte (2014), the debate on sexualities within the scope of Social Work began in 1986, during the National Conference of Social Work Students (ENESS) in Rio de Janeiro - which highlights the protagonism of the student movement already in that time. Since then, sexual diversity has been a topic present in several events of the professional category, such as the Brazilian Congress of Social Workers (CBAS) and the National Conference of Researchers in Social Work (ENPESS), as well as in the consolidation of work and research groups dedicated to the study of the relations of exploitation and oppression of gender, race/ethnicity, generation, and sexuality (DUARTE, 2014).

In turn, Almeida (2008) highlights three crucial factors for expanding the discussion in this professional/academic sphere: the reform of the curriculum of the undergraduate course in Social Work in the 1990s, which now includes the agenda of the LGBT movement among other social movements; the participation of the Student Movement of Social Work (MESS), demanding the insertion of the theme "diversity" in the professional training of social workers; and, finally, the historical and active presence of LGBTs in Social Work college courses.

Despite these initiatives, Marcelino (2010) argues that many of the adversities faced by the LGBT population are still poorly understood or even unknown by Social Work professionals and scholars. According to the author, personal discrimination and intolerance can even affect the way social workers perform their role. Whether due to prejudiced views or due to a gap in college education, the fact is that even today a distorted and dehumanized posture is observed by a portion of professionals in this field. 
This goes against the ethical and professional commitment of Social Work. The goal of social workers must focus on facing the collective needs of society or private groups, demanding that the State fulfill its responsibilities and promoting affirmative social policies with universal outreach. In other words, in their social and technical division of work, social workers need "to capture how the various expressions of the social question are particularized in each socio-occupational space and how they emerge as demands that depend on their professional intervention" (GUERRA, 2007, p. 4, emphasis added). ${ }^{4}$

This position was evident in the video created by CFESS in response to the judicial decision that allowed psychologists to offer sexual (re)orientation therapies, which suggest that homosexuality can be "cured". Recollecting the case: on 9/15/2017, Judge Waldemar Cláudio de Carvalho, from the 14th Federal Court of the Judicial Section of the Federal District, granted a preliminary injunction characterized by the disrespect and retrogression against LGBT rights. In the sentence, he ordered the Federal Council of Psychology (CFP) not to interpret CFP Resolution nr. 01/1999 in order to prevent psychologists from promoting studies or professional assistance pertaining to sexual (re)orientation. ${ }^{5}$

In response to this prejudiced judicial decision, CFESS released on 9/21/2017 a video criticizing the judge's sentence and expressing support for the CFP: For Social Work there is no "gay cure" (CFESS, 2017a, 2017b). In the text accompanying the video, CFESS states that the exercise of Social Work in Brazil must occur without any type of discrimination due to sexual orientation and gender identity, and that the professional category must strive to eliminate all forms of prejudice, encouraging respect for diversity. So they repudiate the injunction of the judge, which hurts the autonomy of the Professional Councils.

\section{The LGBTphobic rhetoric in favor of "gay cure"}

Thus, given the above discussion, the following 15 LGBTphobic comments issued by professionals or students of Social Work will be analyzed hereinafter (see Table 1):

\footnotetext{
${ }^{4}$ According to Iamamoto (2001, p. 10), the social question is understood as the set of expressions of social inequalities engendered in mature capitalist society, unthinkable without the intermediation of the State. It has its genesis in the collective character of production, as opposed to the private appropriation of human activity itself (work), the conditions necessary for its realization, as well as its fruits. "In summary, the social question can be understood as the political manifestation of expressions of social inequality - mediated by unequal gender and ethnicracial relations - resulting from the capitalist production/accumulation process and its inherent contradiction between capital and labor", asserts Meneghetti (2015, p. 157).

${ }^{5}$ It is worth mentioning that, since 1990, the World Health Organization (WHO) established that homosexuality is not a disease but a natural variation of human sexuality. In addition, CFP Resolution nr. 01/1999, based on several scientific studies in the field of Psychology, states: that homosexuality is not a disease, disorder or perversion; that in society there is a certain "uneasiness" around sexual practices considered deviant; and that Psychology should contribute to explaining issues in the area, allowing the overcoming of prejudices. Only in 2018, WHO stopped classifying transsexuality as a mental illness - or, more specifically, as "gender identity disorder" - but still categorizes it as "gender incongruence" in the list of conditions related to sexual health. In April 2019, Minister Cármen Lúcia, from the Supreme Federal Court (STF), granted an injunction revoking the decision that allowed the practice of sexual reversal, stating that homosexuality is not a disease, pathology or deviation and therefore it should not be treated as such. Finally, it was only in January 2020 that the STF gave a definitive judgment on this debate, and decided to maintain CFP Resolution nr. 01/1999, determining that it is not up to psychologists to offer any type of sexual reversal practice, popularly known as "gay cure".
} 


\section{Table 1 - Social workers' LGBTphobic comments}

\begin{tabular}{|c|c|}
\hline ITEM & SENTENCES \\
\hline (01) & $\begin{array}{l}\text { "I recommend to the [CFESS's Facebook] page that if you read and didn't understand the } \\
\text { judge's decision, hire a lawyer to interpret. But if you understand and are trying to cowardly } \\
\text { pursue the judge, I suggest informing it to me here, because I have no part in gay activism } \\
\text { [...] and I prefer to leave." }\end{array}$ \\
\hline $\begin{array}{l}(02) \\
\end{array}$ & $\begin{array}{l}\text { "And now what do you say when a } 12 \text { year old child wants to change their sex because they } \\
\text { think they aren't a man or a woman? And then they regret it when they find out it wasn't } \\
\text { what they wanted, what do you say? [...] Tell me: is this normal?" }\end{array}$ \\
\hline (03) & $\begin{array}{l}\text { "Negative, [the judge's decision] says nothing about "cure", it only authorizes the person who } \\
\text { is gay, if they want, they can try to be straight again. [...] What's the harm in a gay person } \\
\text { wanting to be straight again?" }\end{array}$ \\
\hline (04) & $\begin{array}{l}\text { "CEFSS usually stands in favor of the homosexual agenda, stating that these are goals of } \\
\text { our professional category as a whole, when it is known that those issues weren't discussed } \\
\text { by our entire base. [...] And both in the CEFSS Code of Ethics and in our Constitution, } \\
\text { freedom of thought is guaranteed. In fact, our profession is a clear example that we defend } \\
\text { the contradictory." }\end{array}$ \\
\hline (05) & $\begin{array}{l}\text { "I prefer to stand beside one of the foundations of the Code of Ethics: FREEDOM. And tell } \\
\text { me, where did you read gay cure?" }\end{array}$ \\
\hline (06) & $\begin{array}{l}\text { "Our professional category defends minorities so much, but it survives because of the } \\
\text { majority. And the central issue of the Code of Ethics doesn't seem to be observed properly, } \\
\text { the issue regarding freedom, which includes freedom to contradictory!" }\end{array}$ \\
\hline (07) & $\begin{array}{l}\text { "I didn't read in the judge's decision the term 'gay cure' even used in quotation marks [...]. } \\
\text { This decision is the right to CHOOSE. [...] LGBT manifestations that include public display of } \\
\text { affection, kissing and religious provocation... in the streets in defense of their RIGHTS are } \\
\text { simply deplorable." }\end{array}$ \\
\hline (08) & $\begin{array}{l}\text { "I am a social worker and I defend all rights, especially the right to choose! [...] Yes to the } \\
\text { judge's decision! If you talk so much about respect, respect my professional vision." }\end{array}$ \\
\hline $\begin{array}{l}(09) \\
\end{array}$ & $\begin{array}{l}\text { "Where is the freedom of choice? [...] The judge is simply preserving the right of human } \\
\text { freedom to decide what to do or not to do! It is not up to me or the LGBTS movement, let } \\
\text { alone the CFSS to decide for these people. We have the right to choose." }\end{array}$ \\
\hline $\begin{array}{l}(10) \\
\end{array}$ & $\begin{array}{l}\text { "The psychologist will not cure anyone; they will help those people who have difficulty in } \\
\text { their sexual choice." }\end{array}$ \\
\hline (11) & $\begin{array}{l}\text { "We need to think about our theoretical and methodological basis. We are stuck in a utopian } \\
\text { theory, Marxism, and we aren't managing to reinvent ourselves, to show our role in the } \\
\text { Market! We graduate for the market, not for activism or to live on photosynthesis. Please, } \\
\text { let's take care of Social Work as a profession inserted in the market, as this is better." }\end{array}$ \\
\hline (12) & $\begin{array}{l}\text { "I believe that this is the big problem of Social Work. Only one ideological bias. [...] I am a } \\
\text { Social Worker, but unfortunately I have been very sad every day with the dictatorship of } \\
\text { ideas imposed by the profession. I hope one day that the profession will have a healthy } \\
\text { space to work on these issues. Studying new theorists, new theories, anyway ... Sad." }\end{array}$ \\
\hline (13) & $\begin{array}{l}\text { "There are a large number of conservatives studying Social Work or already graduated, I am } \\
\text { one of them. Prepare yourselves. [...] we are an increasingly growing group of people who } \\
\text { think differently from that left-wing Marxist line." }\end{array}$ \\
\hline (14) & $\begin{array}{l}\text { "Since this [being LGBT] is an aberration, how can it be normal? Funny, they don't accept } \\
\text { their own sex, and they want us to find it natural. Before God, it's an aberration, oh yes. He } \\
\text { loves everyone, but he's angry against sin." }\end{array}$ \\
\hline (15) & $\begin{array}{l}\text { "We are obliged to respect people as human beings, but agreeing with this is different from } \\
\text { what the Bible says [...] I am a social worker." }\end{array}$ \\
\hline
\end{tabular}

Source: CFESS's Facebook page (CFESS, 2017a)

Systematically, it is possible to present the observed results through five analytical categories: the cis-hetero-compulsory rhetoric, the "freedom of thought" rhetoric, the "right to choose" rhetoric, the neoconservative rhetoric and the religious rhetoric. 


\subsection{The cis-hetero-compulsory rhetoric}

The cis-heteronormative model of sexuality and gender identity establishes that cisgender and heterosexual men and women are normal and socially acceptable. ${ }^{6}$ Any other situations that escape this hegemonic and standardized pattern are marginalized, despised, or even stigmatized by socio-political, ideological, religious (among other) practices. Rich (1980) calls this framework "compulsory heterosexuality", arguing that heterosexuality is not natural, but the result of a set of collective practices that impose it as the "correct" way for individuals to relate sexually and emotionally. Bento (2017) amplifies this concept, calling it "heteroterrorism", which prescribes that, if you do not follow the paths of the traditional heteroparental family, you will be expelled from the Nation.

In view of this, pay attention now to sentences (1), (2), and (3). In common, the three comments evoke the pathos of indignation and hostility based on cis-hetero-compulsory rhetoric. They reject CFESS's understanding and defend cisgenerity and heterosexuality as the only forms of socially legitimate and "natural" gender and sexual expression. Therefore, these statements represent discursive strategies of interdiction and control both of the loving and sexual relationships between homoaffective people, and of the possibility of the subjects assuming a gender identity distinct from their biological characteristics.

In commentary (01), the enunciator first assumes the ethos of "expert", stating that CFESS did not understand the judicial decision. Therefore, the Council should hire a lawyer to interpret the judge's sentence correctly - that is, to interpret it as the "expert enunciator" comprehends it. In a second moment, he highlights the victimistic ethos, when associating CFESS's stance as a persecution to the judge. Finally, the enunciator (01) reveals his homophobic and reactionary ethos by declaring that he prefers to withdraw from the Federal Council of Social Work group, since he does not want to have "a part in gay activism".

Comments (02) and (03) incorporate discrediting ethe by inquiring about the "regret" hypothesis of individuals who "change sex" or those cases in which "the person who is gay, wanting to be straight again". Both enunciators start from the fallacious premise that the cisheteronormative model is the only correct and desired one, and that the subjects that deviate from this pattern can feel compunction and want to go back on their decisions. In short, enunciators (02) and (03) disregard that the root of the problem effectively lies in the cisheteronormativity socially prescribed and imposed on the subjects, which castrates the bodies and desires considered as deviants as well as the disruptive identity expressions.

\footnotetext{
${ }^{6}$ The term cisgender (or cissexual or just cis) is used in gender and sexuality studies - as a counterpoint to transgender (or transsexual or just trans) - to indicate people whose gender identity matches their sex assigned at birth. That is, it means an agreement between a person's gender identity, their biological sex and their behavior/social role assessed as socially accepted for that sex.
} 


\subsection{The "freedom of thought" rhetoric}

"Freedom of thought" is one of the most frequent arguments made by those who defend the so-called sexual (re)orientation therapies. The allegations generally involve the Brazilian Constitution and the Brazilian Social Worker's Code of Ethics, with the purpose of justifying virtually any position on the subject and the presumed "right to contradictory", that is, the right to act in disagreement with the very guidance of CFESS.

All ethe built by the enunciators (04), (05) and (06) assume an apparently "libertarian" character. They call for the right to express themselves freely, which gives texts a pathemic effect of independence and autonomy of opinions. In this sense, it is worth mentioning that, in fact, freedom of expression consists of a fundamental right of individuals, guaranteed by article 5, item IX, of the Brazilian Constitution of 1988. However, it is a relative fundamental right, since it is limited by other constitutional rights, such as privacy, honor, image, etc. In other words, any exposition of thought must necessarily respect these rights, therefore repudiating any invasive, prejudiced and discriminatory conduct.

The idea of "freedom to contradictory" claimed by those comments presupposes, in fact, the claim of a carte blanche. That is, an authorization for the social worker to act as they please, with unlimited discretion on how to act professionally in matters related to the LGBT population. Taking the point of view of the judicial decision does not imply the guarantee of "freedom of thought/expression". Rather, such a posture constitutes a blatantly LGBTphobic, intolerant and pathologizing attitude, as it predicts that homo/bi/transsexuality is curable.

\subsection{The "right to choose" rhetoric}

"Right (or freedom) of choice" is also another common justification used to confront CFESS's position. Nowadays, this obsolete fallacy still persists massively in everyday speeches when talking about "sexual option" or "sexual preference" and not about sexual orientation. ${ }^{7}$ Under the "neutral" appearance of words such as choice, option, or preference, underlies the idea that the individual can freely decide whether or not they want to be LBGT. Thus, it reinforces the mistaken common sense that those people who chose to be lesbian, gay, bisexual or transgender - and not "normal" people - would have a deviation in character or behavior. In this line of reasoning, they should therefore be encouraged to choose to be cisgender and heterosexual, as if that depended on individual will or agency.

\footnotetext{
${ }^{7}$ It is worth mentioning that the Brazilian Social Worker's Code of Ethics, since its 2011 edition, has adopted the expression sexual orientation, in place of the previous sexual option: "From the point of view of the content [of the changes in the Code of Ethics in 2011], the changes made were related to the nomenclature modification, replacing the term 'sexual option' with 'sexual orientation', including in principle XI the 'gender identity', when referring to the exercise of social work with no discrimination against this condition. These changes are of paramount importance, as they reaffirm the principles and values of our Ethical-Political Project and incorporate advances in discussions about the rights of the LGBT population through free sexual orientation and expression. Therefore, the changes expressed here are the result of discussions within the scope of the CFESS/CRESS Group, especially on the subject of ethics and human rights" (CFESS Resolution nr. 594/2011).
} 
The pathologization of homosexuality and transsexuality has already been widely contested by the American Psychiatric Association (APA). Similarly to the previous item, a presumably "libertarian" pathemic sense is also articulated by enunciators (07) to (10). They demonstrate ethe of true defenders of the subjects' "sexual choice" right. So they ignore - or pretend to ignore - the prevailing opinion of the academic community that "there is no scientific evidence that sexual orientation, be it heterosexual, homosexual or otherwise, is a freewill choice", as APA (2016) emphasizes.

This sly and shadowy ethos of proponent of freedom is easily unmasked when the repressive, authoritarian, and moralistic tone expressed in other excerpts of these opinions is perceived: "LGBT manifestations that include public display of affection, kissing and religious provocation... in the streets in defense of their RIGHTS are simply deplorable" (07); "[...] respect my professional vision" (08) (emphasis added); "It is not up to me or the LGBTS [sic] movement, let alone the CFSS to decide for these people. We have the right to choose" (09); "The psychologist will not cure anyone; they will help those people who have difficulty in their sexual choice" (10).

At best, these opinions demonstrate complete professional unpreparedness and/or personal ignorance about structurally and socially institutionalized LGBTphobia, considered as the main cause of the difficulties of self-acceptance and self-esteem faced by members of the gender and sexuality diverse community (LOURO, 2009). Actually, the problem does not lie in dissident sexualities nor in dissonant gender identities per se. Rather, it resides in the consequences left by the unfounded phobia crystallized in society, when perceiving the LGBT population as a serious threat to the traditional cis-heteronormative values.

\subsection{The neoconservative rhetoric}

Another group of comments can be gathered based on the arguments in favor of an alleged new traditionalism or, more precisely, of a libertarian conservatism (LYNCH, 2017). This notion refers to a political ideology that associates socio-conservative principles with neoliberal economic tactics. Massively present in Brazilian society in these days, this rhetoric assumes a political conservatism bias under the strong influence of economic liberalism. In short, it is the portrait of the current policy adopted by the federal Brazilian government: "liberal conservatives" combine traditionalist actions related to the behavior and morality of the social body with predatory capitalist practices in economic matters.

Ferreira and Botelho (2010) assert that there is a conservative Brazilian thinking, inherited from our colonial and slave past. It is characterized by certain principles and values (order, authority, discipline, hierarchy, "meritocracy"), structured in theories and pedagogies that ended up producing anti-democratic tendencies and anti-communist paranoia, in addition to the formation of a political culture contrary to the idea of workers' rights. 
Thus, in comments (11) to (13), we can observe that terms such as "Marxism" (11), "Marxist" (13), "ideological bias" (12), "dictatorship of ideas" (12) and "left-wing line" (13) are rejected. On the other hand, expressions such as "market" (11) and "conservatives" (13) are highlighted. It is the so-called postmodern neoconservatism in Social Work (SANTOS, 2007).

Here, the predominant pathos is the non-conformity with the current position of the Brazilian Federal Council of Social Work and the Social Work degree course. In this sense, social workers (11) and (12) and college student (13) show ethe typically neoliberal. That is, they flatly refute the alleged "left-wing Marxist" orientation of Social Work programs and, by extension, CFESS's position in the face of the LGBTphobic judicial decision. Under the pretext of studying "new theorists, new theories" (12), these enunciators exalt capitalist and economist practices, coated with a moralism typically founded on thoughtless archaic precepts, disregarding the complexity of this discussion.

\subsection{The religious rhetoric}

In Brazil, the relationship between religion and Social Work is not recent. In fact, as Simões (2005) claims, the emergence of the profession in Brazil refers to the 1930s, a time of great industrialization and urbanization in the country. In order to control the growing popular discontent and social misery - stemming from the antagonism between the socialization of production and the private appropriation of the fruits of labor - the Vargas State (1930-1945) and the industrial bourgeoisie joined forces with the Catholic Church to initiate the direct implementation of social policies. Therefore, Social Work has its genesis based on Christian religious values, revealing a close relationship with the ideas of charity and philanthropy. For Simões (2005, p. 11):

[...] the profession [social worker] arises from religious groups. However, the affirmation of this "myth of origin" does not guarantee, in principle, that it will perpetuate itself indefinitely. It will therefore be necessary to show what empirical foundations support the reproduction of this mediation in professional practice and what its expressions of continuity are.

According to Netto (2004), the epistemological turn of Social Work occurred in the 1960s, detaching itself from the welfare doctrine of the Catholic Church and the North American positivist method, which did not foster concrete transformations in the social order. Nowadays, Social Work in Brazil consists of a profession with a socio-political, critical, and interventionist nature, recognized and socially legitimized. It uses the multidisciplinary apparatus of human and social sciences with the purpose of analyzing and intervening in the various expressions of the "social question".

Furthermore, the social worker is a professional committed to the values and principles expressed in the Brazilian Social Worker's Code of Ethics, which expressly prohibits any form of discrimination based on sexual orientation. It is not what you see in 
comments (14) and (15). Social workers (14) and (15) assume religious ethe, even calling LGBT people an "aberration" (14). The professional guideline of these enunciators is not the Social Worker's Code of Ethics, but the Bible (15) and the wrath of God (14). The pathemic effect here is religious fear. Thus, the two young social workers demonstrate that their religious convictions are intimately imbricated to their professional practice. In this way, it is possible to conclude that such a posture differs diametrically from the critical perspective anchored in dialectical historical Marxism, which underlies the thinking of Brazilian Social Work in contemporary times.

\section{Final considerations}

As it was possible to observe from the comments of internet users in the publication of the CFESS's video For the Brazilian Social Work, there is no "gay cure", a portion of the social workers and college students still sustains a markedly LGBTphobic rhetoric. Whether due to political, ideological or religious convictions, or due to a cis-heteronormatizing view of sexualities, or even due to a misinterpretation of the notion "freedom of expression" in the Brazilian Constitution and the Social Worker's Code of Ethics, part of the professionals ends up reverberating a prejudiced and reactionary perception towards members of the gender and sexuality diverse community.

However, it should be noted that, as explained by Daniela Neves (2017), vicepresident of CFESS:

This is what really sickens and kills the LGBT population: the prejudice and discrimination of society. Therefore, the social worker who defends the position of the magistrate, and who thinks that homosexuality is a disease that can be cured, is disregarding the whole debate that the Brazilian Social Work has been making for more than a decade about the defense of LGBT rights. You may even be committing an ethical infraction if, in a service to an LGBT person, you say that they can be 'cured', as if their sexual orientation was the problem.

In conclusion, we must emphasize that there is an urgent need to expand the debate on the professional practice of Social Work in favor of the gender and sexuality diverse community. Because it is a professional category that deals directly with the LGBT population, it is essential that social workers reflect on their ethical commitment and the importance of their role and their actions in defense of these people who are often so vulnerable and stigmatized in the social, political, economic, legal and affective spheres. 


\section{References}

ALMEIDA, G. Notas sobre a possibilidade de enfrentamento da homofobia pelos/as Assistentes Sociais. O Social em Questão, v. XI, n. 20, p. 117-141, nov. 2008.

AMERICAN PSYCHIATRIC ASSOCIATION (APA). Homosexuality as a mental disorder simply not backed up by science, 10 Mar. 2016. Available at: http://bit.ly/2n9ltLm. Accessed: 14 June 2020.

ARISTÓTELES. Retórica. São Paulo: Rideel, 2007.

BENTO, B. Transviad@s: gênero, sexualidade e direitos humanos. Salvador: EDUFBA, 2017.

CHARAUDEAU, P. A conquista da opinião pública: como o discurso manipula as escolhas políticas. São Paulo: Contexto, 2016.

CHARAUDEAU, P. Pathos e discurso político. In: MACHADO, I.L.; MENEZES, W.; MENDES, E. (Orgs.). As emoções do discurso. Vol. 1. Rio de Janeiro: Lucerna, 2007. p. $240-251$.

CONSELHO FEDERAL DE SERVIÇO SOCIAL (CFESS). Para o Serviço Social Brasileiro, não existe "cura gay". Facebook, 21 Sep. 2017a. Available at: http://bit.ly/2ktL4P6. Accessed: 14 June 2020.

CONSELHO FEDERAL DE SERVIÇO SOCIAL (CFESS). Para o Serviço Social Brasileiro, não existe "cura gay". YouTube, 21 Sep. 2017b. Available at: http://bit.ly/2kTwnEW. Accessed: 14 June 2020.

CONSELHO FEDERAL DE SERVIÇO SOCIAL (CFESS). Resolution nr. 273, 13 Mar. 1993. Institutes The Brazilian Social Worker's Code of Ethics.

DUARTE, M.J.O. Diversidade sexual, políticas públicas e direitos humanos: saúde e cidadania LGBT em cena. Temporalis, v. 14, n. 27, p. 77-98, jan./jun. 2014.

FERREIRA, G.N.; BOTELHO, A. (Orgs.). Revisão do pensamento conservador: ideias e política no Brasil. São Paulo: Hucitec/Fapesp, 2010.

FREIRE FILHO, J. A comunicação passional dos fãs: expressões de amor e de ódio nas redes sociais. In: INTERCOM, 36., 2013, Manaus. Anais... São Paulo: Intercom, 2013.

GUERRA, Y. A instrumentalidade do Serviço Social. 5.ed. São Paulo: Cortez, 2007.

IAMAMOTO, M.V. A questão social no capitalismo. Temporalis, v. 2, n. 3, p. 9-61, jan./jun. 2001.

LEACH, J. Análise retórica. In: BAUER, M.W.; GASKELL, G. Pesquisa qualitativa com texto, imagem e som: um manual prático. Petrópolis: Vozes, 2002. p. 293-318. 
LOURO, G.L. Heteronormatividade e homofobia. In: JUNQUEIRA, R.D. (Org.). Diversidade sexual na educação. Brasília: MEC; Unesco, 2009. p. 85-93.

LYNCH, C.E.C. Conservadorismo caleidoscópico: Edmund Burke e o pensamento político do Brasil oitocentista. Lua Nova, n. 100, p. 313-362, 2017.

MARCELINO, S.R.S. Questões contemporâneas: a homossexualidade e os novos sujeitos como desafios para o Serviço Social. In: SEMINÁRIO INTERNACIONAL FAZENDO GÊNERO: Diásporas, Diversidades, Deslocamentos, 9., 2010, Florianópolis. Anais... Florianópolis: UFSC, 2010.

MAINGUENEAU, D. A propósito do ethos. In: MOTTA, A.R.; SALGADO, L. (Orgs.). Ethos discursivo. São Paulo: Contexto, 2008. p. 11-29.

MATEUS, S. Introdução à retórica no séc. XXI. Covilhã: LabCom.IFP/UBI, 2018.

MENEGHETTI, G. Questão social - afinal, do que se trata? In: AMARO, S. (Org.). Dicionário crítico de Serviço Social. Rio de Janeiro: Autografia, 2015. p. 154-164.

MENEZES, M.S.; SILVA, J.P. Serviço Social e homofobia: a construção de um debate desafiador. Katál., v. 20, n. 1, p. 122-129, jan./abr. 2017.

MOZDZENSKI, L. O ethos e o pathos em videoclipes femininos: construindo identidades, encenando emoções. 2012. 356f. Tese (Doutorado em Linguística) - Centro de Artes e Comunicação, Universidade Federal de Pernambuco, Recife, 2012.

NETTO, J.P. Ditadura e Serviço Social: uma análise do Serviço Social no Brasil pós-64. 7.ed. São Paulo: Cortez, 2004.

NEVES, D. Em vídeo, CFESS contesta decisão judicial que abre precedentes para terapias de reorientação sexual. CFESS, 22 Sep. 2017. Available at: http://bit.ly/2oajJD9. Accessed: 14 June 2020.

$\mathrm{RICH}$, A. Compulsory heterosexuality and lesbian existence. Signs, v. 5, n. 4, p. 631-660, 1980.

SANTOS, J.S. Neoconservadorismo pós-moderno e Serviço Social brasileiro. São Paulo: Cortez, 2007.

SIMÕES, P. Assistentes sociais e religião. São Paulo: Cortez, 2005.

UNITED NATIONS HUMAN RIGHTS COUNCIL (UNHRC). Resolution A/HRC/RES/17/19, 17 June 2011. Resolution adopted by the Human Rights Council on Human rights, sexual orientation and gender identity.

VAN DIJK, T.A. Critical Discourse Analysis. In: SCHIFFRIN, D.; TANNEN, D.; HAMILTON, H. E. (Eds.). The handbook of discourse analysis. Oxford: Blackwell, 2003. p. 352-371. 
VECCHIATTI, P.R.I. Manual da homoafetividade: da possibilidade jurídica do casamento civil, da união estável e da adoção por casais homoafetivos. 3.ed. Bauru: Spessotto, 2019. 